\title{
- HELSEARBEIDERE KAN IKKE OPPTRE APOLITISK
}

\section{I et leserinnlegg i Dagbladet forsvarer sykehusdirektør Tor Ingebrigtsen Mads Gilbert og Erik Fosses arbeid} og ytringer. - Humanitært og samfunnsmedisinsk arbeid er i sin natur politisk, sier han.

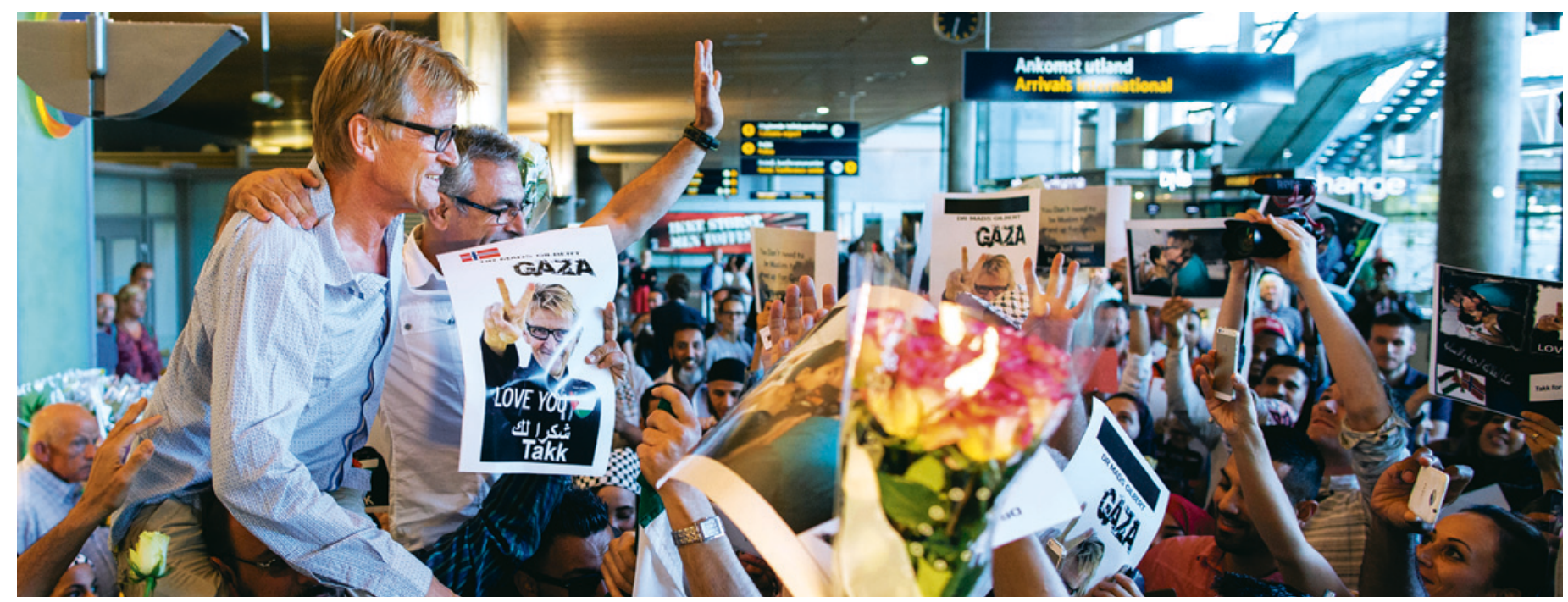

Mads Gilbert og Muhammad Abou Arab blir hyllet idet de ankommer Oslo lufthavn etter at de hadde vært i Gaza. Foto: Vegard Wivestad Grøtt/NTB scanpix

Bakgrunnen for kommentaren (1) er kritikken mot Mads Gilbert og Erik Fosse for å drive politisk virksomhet som leger. Sykehusdirektøren ved Universitetssykehuset Nord-Norge mener det er helt naturlig at det blir politikk ut av det.

- Helsearbeidere kan ikke opptre apolitisk, for humanitært og samfunnsmedisinsk arbeid er i sin natur politisk. Det er urimelig å forvente at den enkelte helsearbeider, fra sitt observasjonssted, skal formidle et komplett og balansert bilde, men formidling er likevel helsearbeiderens plikt, skriver Ingebrigtsen.

Mads Gilbert har i årevis vært engasjert $\mathrm{i}$ internasjonalt humanitært arbeid, og er særlig kjent for sin innsats i Gaza. Han er også en ivrig talsmann i mediene, noe som har skapt mange diskusjoner. Men sykehusdirektøren mener dette er helt riktig.

- Mitt hovedpoeng er at krigen i Gaza, som alle andre kriger, medfører uakseptable helseskader og lidelser for sivilbefolkningen. Politikerne må snarest finne løsninger for å stoppe dette. God faglig formidling av krigens konsekvenser, slik Gilbert og Fosse har stått for, gir politikerne den informasjonen de trenger for å forstå at krigen må stoppes. Det er vanskelig for andre enn dem som tar imot pasientene og ser skadeomfanget å beskrive lidelsene godt nok, og det er derfor en plikt for helsearbeidere som får anledning til det å sørge for slik formidling, sier Ingebrigtsen i en kommentar til Tidsskriftet.

Medisin handler om mer enn å behandle pasienter. Ingebrigtsen mener helsearbeidere også skal rapportere og analysere og gjennom rapportene påvirke politiske beslutninger.

- Årsaken til og omfanget av helseskadene må beskrives, og forebyggende tiltak må foreslås. I den tidlige fasen vil øyeblikksbildet dominere. I neste fase kan observasjonene systematiseres, bearbeides vitenskapelig og publiseres i fagtidsskrifter, slik Gilbert gjorde i The Lancet etter forrige krig i Gaza, mener Ingebrigtsen.

\section{Ole Kristian Losvik}

Tidsskriftet

\section{Litteratur}

Litteratur
1. Ingebrigtsen T. Kritikken er meningsløs. Dagbladet 1.8.2014. www.dagbladet.no/2014/08/01/ kultur/meninger/kronikk/mads_gilbert/gaza/ 34590447/ (4.8.2014).
«Helsearbeidere kan

ikke opptre apolitisk, for humanitært og samfunnsmedisinsk arbeid er i sin natur politisk»

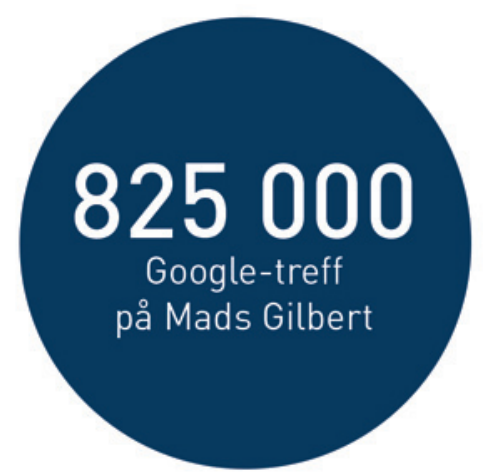

